\title{
The Literature of Love from the View Point of Theosophy
}

\author{
Khalil Bahrāmi Ghasrechami \\ PhD - Islamic Azad University, Dehaghan Branch \\ Hosein Āryān \\ PhD in Persian Literature - Zanjan University \\ Yaldā Bābāyi \\ PhD Student in Islamic Gnosticism, Azad University \\ (Najafabad Branch) - Ministry of Education, District 2 of Isfahan \\ Manizheh Bahādorān \\ Ministry of Education - Education Department of Falavarjan \\ Shahlā Mokhtāri \\ Ministry of Education - Education Department of Falavarjan
}

Doi:10.5901/mjss.2015.v6n6s4p203

\begin{abstract}
One of the definitions of love, given by Scholars and intellectuals, is to like something or someone enormously or to be fond of something. The term, "eshq" (the Arabic equivalent of love) with the root "ashaq" and "ashaqeh", has occupied the mind of many experts and scholars. Sometimes its position seems so high that it is called the bird of eternity and the lifelong traveler which nests in the glory of eternity. This research, by applying an analytical method, aims at showing different views of scholars and intellectuals, defining the term "eshq" in brief firstly, and then to emphasize that although the term "eshq" itself is not mentioned in Quran, its equivalents are detected in Quran, and that unlike Quran, theosophical texts and narratives have included the term many times. Love has been divided into different types and has different stages. The most famous division is virtual and true love. True love is to love God and His characteristics and virtual love is a sensual one which is limited by wisdom.
\end{abstract}

Keywords: love, lover, beloved, God, man, true love, virtual love.

\section{Introduction}

Love, i.e. "eshq" with the Arabic stem "ashaq", has been defined differently in different books. Some see it as full love and some consider it as really strong attachment. Ibn Arabi (2001) believes that those who define love don't understand it and that love is the kind of drinking which satisfies the thirst of no one.

Louis Massignon says the first theosophists didn't use the term "eshq" being afraid of earthly love, so they tend to refer to the concept as tenderness. Some consider love as the reason of the existence of all of the creatures which is the love of God toward His own beauty. God created the universe due to His love toward His nature and beauty. Hence, the first one who loved was the eminent God. It is based on this love toward His own essence that He loves His creatures.

However, it is suggested that there are two reasons for the creation of love, both rooted in the human nature. First, man's natural tendency toward seeking perfection, that is, man tries to obtain everything to improve and fulfill his natural capacity. The second reason is his natural tendency toward seeking beauty because total perfection may lead to beauty or a feature of beauty, which is an important factor in creation and realization of love. Actually, understanding the beauties of the universe leads to love toward the Creator. And this is the love which religion portrays for the man. Investigating the verses of Quran, we come to this conclusion that the term "eshq" is not used in Quran. However, it is 
seen in theosophical texts and narratives frequently.

Based on the findings from investigating views and records about the stages of love, it can be emphasized that various classifications of love have been proposed; one of them is dividing it into virtual and true love. This paper is an attempt to illustrate the differences between true love and virtual love form different perspectives by investigating the emergence and use of the word love or its equivalents in Quran and theosophical texts.

\section{The Root of "Eshq" (The Arabic Equivalent of Love)}

Love and its deep meanings are widespread in our culture to the extent that one cannot reach its depth. Before defining love and talking about its being theosophical, it is needed to investigate the root of the term "eshq", the Arabic equivalent of love.

Jami (1989) believes that 'eshq' is taken from 'ashaqeh' which is a plant that is called 'sen'; we call it 'eses'; in Neyshabur, it is called 'serend'; in Jam, 'ooghi'; and in Zozan 'erghi'. It is a kind of plant that no one knows where it grows and when it grows; it is seen when it has looped around the tree and reached the top and has had the tree to display its characteristics; No matter how much you try and how hard you try, you won't succeed to make them apart.

Some believe that love is to like something or someone enormously using words like infatuation and strong friendship (Amid, 2002) and some have defined it as total kindness. According to Novin Dictionary, love is strong attachment to something (Gharib, 1977).

Deilami, getting help from sayings by scholars, philosophers, Sunni speakers, and Sufi sheikhs, believes 'eshq' is taken from 'ashaq' which is the highest point of a mountain; so, when it is said that someone is in love, it means that his kindness toward the beloved is in its highest point.

\section{Defining Love}

Scholars and intellectuals have tried to elaborate on the concept of love and each one of them has described it in their own way. However, they all agree that defining the truth of love is not possible. Because based on their beliefs neither is love tangible nor can the human wisdom and reason help to understand it. Another offered definition is seething kindness and its final stages.

Avicenna (1979), the great Iranian philosopher and scientist, has defined love too. He sees it as the cause of the existence of all of the creatures and believes that it is a divine gift which everyone enjoys in some way. Mulla Sadra, another Iranian philosopher, agrees with Avicenna and believes that all the creatures are full of love and there's no one who is without love (Ghavam-e Shirazi, 2010-2013).

Also, love is called the bird of eternity and the eternal traveler nests in the glory of eternity. If, sometimes, it flies away from this resting place, it will return to this glorious and pre-eminent position. That's why love has not shown its beauty to anyone clearly and reaching the depth of its truth and its hidden secret has not been possible yet(Ebrahim Dinani, 2001).

Khomeini (2001), another expert in the field, believes that love exist in the nature of human beings and the man and His creator are related and connected to each other due to love. If love was not something natural, none of the creatures would be created and nothing could achieve perfection in any way. He assumes a high position for love and emphasizes that skies are firm based on love and love is the secret of creation. Love, according to Suhrawardi (1954), is an upright tree with its roots in spiritual domination.

\section{Love in Quran}

The term "eshq" is not mentioned in Quran even once. But, there are some other words included in some of the verses which connote meanings like kindness and amity. Below are some of these verses:

God will bring a folk whom He loves and they love Him (Al-Maeda, verse 54).

And Allah loves those who are firm and steadfast (Al-i-Imran, verse 146).

Truly Allah loves those who fight in His Cause in battle array, as if they were a solid cemented structure (Saff, verse 4).

To explain the point that the term "eshq",itself, is not used but its connotations are founded in Quran, it has been claimed that, "if someone says 'eshq" is not mentioned in Quran, we say that's right. Nevertheless, lots of reliable reports include the words "eshq" and "asheqi" (the Persian equivalent for being in love). Anyway, a group of Sufi masters and 
scholars have asserted that they didn't use the term since it leads to ambiguity (Jami, 1989).

In addition to some equivalents of love seen in Quran, whenever a story of prophets (e.g., Abraham, Ayoub, Joseph, Muhammad, etc.,) is being told, the concept of love is introduced. The courage of Abraham when he picked the axe and breaks the idols into pieces one by one under the order from his beloved, God, and the patience of Ayoub and bearing hardships and disasters due to his love toward his beloved, God, both show this true love.

The story of Joseph in Quran has introduced two types of love; one is the paternal love of Jacob toward his son, Josef, and the other is the sensual love of Zoleikha toward Josef. "These two are the examples of earthly love and human love, none of which is intrinsically wrong. The love of Jacob toward Josef was so intense that caused him great sorrow; their separation made him blind and their reunion cured him. This love lies in line with God. Since the messengers of God are far from having mere human sensual tendency and pursuing human passions" (Mohammadi, 2003). It has been said that Sheikh Shattah said, "The love of Jacob toward Josef is a cogent reason for human love. For, it was nothing but divine love and beauty is a help to discover God's beauty (Mohammadi, 2003).

\title{
5. Love in Narratives
}

Love is seen clearly in Islamic Hadiths and narratives. There are few religious books which do not refer to love. What seems important to some is the limited or no use of the term itself in narratives; like in narratives quoted from Imams. For example, Imam Ali (PBUH) says, "When one loves a thing it blinds him and sickens his heart". It can be said that Imam Ali (PBUH) didn't mean to blame love; but, on the contrary he has mentioned a nice feature of love.

There are lots of narratives which explicitly discuss love. These narratives are presented in "The Oceans of Light" and "Al-Kafi" under different chapters like faith and atheism, heaven and Salman, love and chastity, and so on. According to "Al-Kafi" Prophet Muhammad said, "The best is the one who comes to love prayers, goes with it hand in hand, loves it by heart, does it using his organs, and makes himself free to do it; such a person does not concern whether he is living in difficulties or at ease" (Kulayni, 1993). Also, it has been said that Imam Ali (PBUH) said, "The end to love is separation" (Majlisi, 1999). Although the term "eshq" is not mentioned in Quran, there are lots of different narratives about it.

\section{Love in Theosophical Texts}

Theosophy means the wisdom of God; it is a system of philosophy which tries to find the mysteries of nature and being especially the nature of divinity (Wikipedia, 2015). It may manifest itself in the form of literature. The term "eshq", meaning excessive kindness, has been used in literary texts a lot; as in the following poem by Fakhr-al-Din Iraqi (1983), a poet of the seventh century:

\author{
When love comes to perfection \\ In the heart comes the colour of beauty \\ People of thought call it love \\ When it comes to the extreme end
}

By studying Arabic poetry and literature and comparing Persian poetries with poetries in other languages, it can bee seen that the environment in which Persian poets lived was totally different from their counterparts; the environment and difficulties in which other poets lived was not suitable to raise poets who compose love poetry. Only some of them like Nizar Qabbani and the poets of lyrics like "Layla and Majnun" have the concept of love in their poems; Love is specific to Persian sonnets. The author of the book "The States of Pure Love" addresses this point that, not taking the ideological base of the works of Hallaj and Bayazid into account, defining the process of the development of love in Persian poetry needs tracing a path which starts with Sanai, reaches its highest point by Attar, Iraqi, and Saadi, and finally comes to meditation by Mawlānāand Hafez. He believes that considering love poetry by Nizami, Anvari, etc. is necessary (Gharagozlou, 1998).

\section{The Classification of Love}

Love has been classified into different types and has different stages. Some (e.g., Ayn al-Quzat Hamadani) have divided it into three types including great love, the love of God toward His servants, minor love, the love of servants toward God, and medium love. We hope that God will tell us a bit more, secretly (Ayn al-Quzat Hamadani, 1962).

To explain this idea, it is said that these three stages are justifiable and interpretable due to their being symbolic. 
Philosophers have put different interpretations on these three. Those interpretations themselves need to be discussed exhaustively. Anyhow, what can be learnt from these three is that they can be defined as follows: great love is related to recognizing the nature of God, medium love is related to recognizing His characteristics, and minor love is related to recognizing His acts and effects. Also, it is possible to interpret the last one as materialistic and superficial love due to the term minor. This point is justified in case we accept that love toward God cannot be accompanied by and related to the term minor since it means being small and not serious(Mohammadi, 2003).

According to another classification made by experts of the field, love is true and virtual. Mulla Sadra is one of those who admit this classification. In his book, "The Transcendent theosophy", he mentions this point that true love is expressing kindness toward God and His acts and virtual love has some stages which starts with sensual love and ends with wisdom (Ghavam-e Shirazi, 2010-2013).

Virtual love is named differently in different literary texts including prose and poetry. For example, Mewlana sometimes calls it either colored or pink love and sometimes refers to it as a three-day love. In addition, according to the works of great experts of literature and theosophists, virtual love is referred to as superficial, temporary, materialistic, erotic, worldly and earthly(Mohammadi, 2003).

\subsection{True love}

True love is but love toward God. In the opinion of theosophists, true love is the one which leads to God and love toward someone other than Him is false and fueled by passion. On the other hand, some believe that love toward God, His creatures, whatever takes place due to divine acts and effects, prophets, messengers of God, and divine authority can be assumed as true love (Mohammadi, 2003).

Jalaluddin Ashtiani believes that the truth of love, in the spiritual world, is far from noticing the feeling of love and the beloved. Rather, it is sheer love which is far from limitations or imitation. In this stage, the lover fades into the beloved beauty and both are faded in the truth of love (Khomeini, 2001).

However, Imam Khomeini (RA) sees the universe as the shadow of God. According to him the true beloved causes the universe to be created and the universe is created under the shadow of the true beloved. From the viewpoint of Ibn Arabi, the true lover is the eternal beauty which is not hidden and that it tends to emerge and is enthusiastic about His manifestations. He believes that God's emergence happens because of the mixing of the God and man and that love is a mirror reflecting the lover and his accomplishments (Ibn Arabi, 2001).

Imam Khomeini considers caliphate, authority, and being loved as three signs of God. To support this interpretation, it is said that, throughout his poetry collection, he has referred to love 167 times, using beautiful collocations like the secret of love, the confident of love, the breeze of love, the religion of love, the love tent, the school of love, shambles of love, the ocean of love, the love hadith, the sanctum of love, and the like and has used the term "lover" 48 times. Nonetheless, the term "beloved" with all its beauty is mentioned once in this poetic work; in a sonnet which seems to show the dignity of one who reflects the beloved being of God(Mohammadi, 2003).

In the book "Forty Hadiths", the way man is described connotes that only he deserves to be God's Caliph and that he can reach the point that God accepts him to be Him (Khomeini, 2005). The lover who loves the God's creatures in the way God does and considers this high position love and the beauties of the world as part of the dignity of God becomes God's caliph (Mohammadi, 2003).According to Jafari, true love is the love experienced by the lover facing calenture; the more calenture the lover feels the easier and the more possible the reunion. This type of love is the one which is eternal and everlasting, shining brilliantly; the love toward the Beloved who is eternal and undying and like the sun which absorbs every particle, attracts the fellow lover. And the reunion is possible for this lover when he changes to Him, the Beloved. Just like a drop which is a drop until it is a drop and when it stops being a drop and believes its existence, the reunion has taken place (Jafari, 2007).

\section{Jafari cites a poem by Hafez as evidence to explain his viewpoint: In one glance, men of vision stake two worlds, \\ This love; and, on life's casts, the first stake, one can cast}

True theosophists have talked about love whenever they wanted to guide the man into perfection and cognition. Sheikh Ahmad Ghazali takes this point into consideration that the man is a beloved before being a lover. He emphasizes that being a beloved and a lover is of characteristics of the Almighty God and the man is the only creature who is recognized as the perfect symbol and the full expression of the eternal characteristics of God (Ebrahim Dinani, 2001). He believes that true reunion takes place when both the lover and the beloved fade into love and there's nothing left except 
the truth of love. He justifies the problem of separation and the beloved escape from the lover suggesting the same reason. The reason is that realizing the truth of reunion is extremely difficult; to realize it, the lover should become selfless and the beloved should accept that he is not a beloved any more but is the same as the lover (Ebrahim Dinani, 2001).

\subsection{Sensory and virtual love}

It can be said that the first stage of love is sensory love. Not only the man but also many animals feel such a love. Through this kind of love, when the lover meets his beloved, he loses his heart to the beloved and the beloved is trapped in this love, too. The lover wants the beloved for him only, he is in the honor of the beloved, and is always worried about the beloved loss. Being excited, fervent, and depressed is of characteristics of the lover experiencing such a love. He gets to the point that he is not afraid of annoying his beloved. Such a lover is sacrificed on marriage and, little by little it fades, dies, and even sometimes it changes into mutual hatred.

If the man falls in such a love, after he is full of hatred, he tries to compensate for what has happened in the past, and perhaps he becomes an enemy of his beloved. In this regard, Mulla Sadra says, "perhaps the lover becomes the most formidable enemy" (Ghavam-e Shirazi, 2010-2013).

This is true for the lover who nurtures such a love in his heart. Once his love dies and changes into hatred, he is the enemy of his beloved and tries to harm the beloved.

Maybe that they believe love can change into hatred means the end of love and perhaps one of the interpretations of Imam Ali saying, i.e. "When one loves a thing, it blinds him and sickens his heart.

Hamedani (2008) sees the wisdom behind this kind of love as removing all the concerns and sorrows from hearts of lovers and making them unified so that the lover's mood raises and reaches the stage after which there is no end and no dependence; it is completed by the kindness toward the One Who is eternal. He sees such a love as virtual and a path to the truth of kindness. It should be noted that it is needed for the man not to stay on but to pass this path; he should try hard to make use of this opportunity and reach the true love, i.e. the divine love.

\section{Conclusion}

The term "eshq" taken from the root "ahaqeh" has occupied the minds of many thinkers, scholars, and writers and has been under especial focus in many books. The concept of love is found in Quran, narratives, and theosophical texts. However, the term itself is not cited in Quran. Of course, its equivalents like "hobb" (the Arabic equivalent for liking) and "mohebbat" (the Persian equivalent for kindness) are included in its verses. Love has been defined as dependence, attachment, infatuation and the like. Dividing it into virtual and true loves is the most famous classification made by scholars. Virtual love is an opportunity and a pathway toward true love, that is, the divine love.

\section{References}

Ahmadi, B. (n.d.). Four Reports on the authorities' biogrophies by Attar.

Amid, H. (2002). Amid Dictionary. Tehran: Amir Kabir.

Ayn al-Quzat Hamadani, A. i. (1962). Preludes. Tehran: Tehran University.

Ebrahim Dinani, G. H. (2001). The Book of Wisdom and the Sign of Love. Tehran: Tarhe No.

Gharagozlou, M. (1998). The States of Pure Love. Tehran: Muhammad Gharagozlou Publication.

Gharib, M. (1977). Novin Dictionary. Tehran: Bonyad.

Ghavam-e Shirazi, S. a.-D. (2010-2013). The Transcendent theosophy in the Four Journeys of the Intellect. (M. Khajavi, Trans.) Tehran: Moula.

Hafiz, K. S.-U.-D. (2002). Hafiz Poetry Collection. Kerman: Cultural Service institution of Kerman.

Hamedani, A. S. (2008). The Ocean of Knowledge. (H. Ostad Vali, Trans.) Hekmat.

Ibn Arabi, M. (2001). Cloves Government (Vol. 2).

Ibn Sina, H. i. (1979). treatises. Qom: Bidar.

Iraqi, F.-a.-D. I. (1983). The Book of Lovers. Day.

Jafari, A. (2007). The Wooden Leg of Reason on the Way to Love. Journal of Theosophy(13).

Jami, A. (1989). Sincerety of repentants. (A. Fazel, Ed.) Tehran: Toos.

Khomeini, R. (2001). The Lamp of Guidance into Vicegerency and Sanctity. Tehran: The Institute for Compilation and Publication of Imam Khomeini's Works.

Khomeini, R. (2005). Forty Hadiths. Tehran: The Institute for Compilation and Publication of Imam Khomeini's Works.

Kulayni, M. i. (1993). Al-Kafi. (M. B. Kamare'ie, Trans.)

Majilisi, M. B. (1999). Oceans of Light. Tehran: Islamic Culture Publishing Office. 
Mohammadi, K. (2003). The Survival Spring. Tehran: Ministry of Culture and Islamic Guidance.

Suhrawardi, S. a.-D. (1954). The Mate of the Lovers. (H. Mofid, Ed.) The Institution of research and publication of Imams' instructions. Wikipedia (2015), Theosophy, retrieved September 1, from https://en.wikipedia.org/wiki/Theosophy 